\title{
The Domestic Economy in Transition
}

\author{
Recent indications of growth follow stimulative \\ monetary and fiscal actions
}

INCE EARLY SPRING the economy has indicated a renewed strength in contrast to the weakness exhibited through the fall and winter. After slowing for several months, consumer spending on goods and services and business investment in plant and equipment apparently have started to rise again. This improvement in total spending follows stimulative monetary and fiscal actions taken during the winter.

The U.S. balance-of-payments deficit has shown little improvement thus far in 1967. There is some concern that the deficit will increase substantially this year over 1966 , particularly in view of declining short-term interest rates in the United States. However, some foreign interest rates have also fallen, and this may reduce such concern.

\section{Whathon}

Total spending slowed markedly in late 1966 and early 1967 , and real output showed no growth. Industrial production, which represents about one-third of real output, declined at a 4 per cent annual rate from October 1966 to March 1967.

A sharp increase in inventories held by businesses

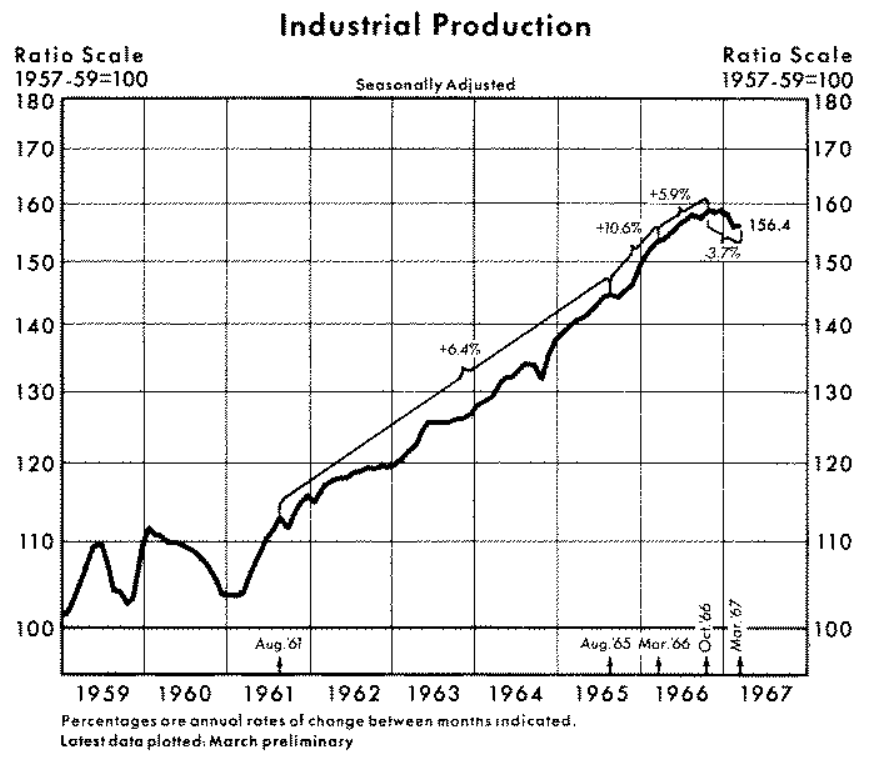

relative to their total sales was another indication of weakness in the fall and winter months. The inventorysales ratio rose at a 12 per cent annual rate from August to February. This measure tends to rise as the pace of economic activity slows because production usually adjusts to weakness in sales with a lag of several months. As inventories build up relative to sales, they generally act as an additional drag on economic activity. Businesses reduce inventories to more efficient levels by slowing production. Final sales, which is measured by total spending minus inventory investment, showed some improvement in early 1967. From the fourth quarter of 1966 to the first quarter of 1967 , these sales increased at a 9 per cent annual rate compared with a 7 per cent increase during last year.

The upward pressure on commodity prices moderated as spending slowed. Consumer prices increased at a 1.8 per cent rate from August to March compared with a 3.5 per cent rate of increase in the previous year. Wholesale prices declined at a 2 per cent rate from August to March, reflecting primarily a 15 per cent rate of decline in prices of farm products. Wholesale industrial prices increased at a 1.3 per cent annual rate, somewhat slower than the 2,4 per cent rise in the previous year.

The decline in farm commodity prices since late summer has pertained both to crops and to livestock products. Of the crops, soybean prices have shown

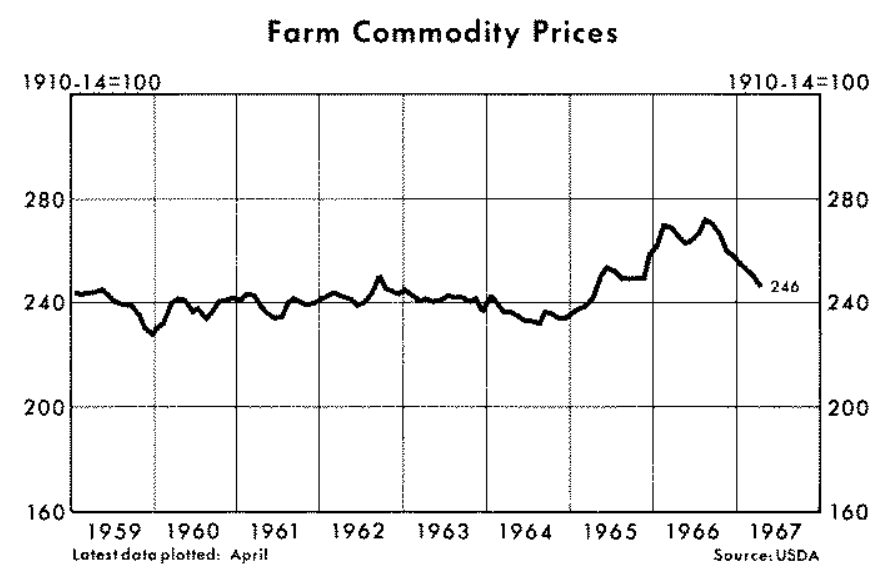


Inventories Compared With Monthly Sales*

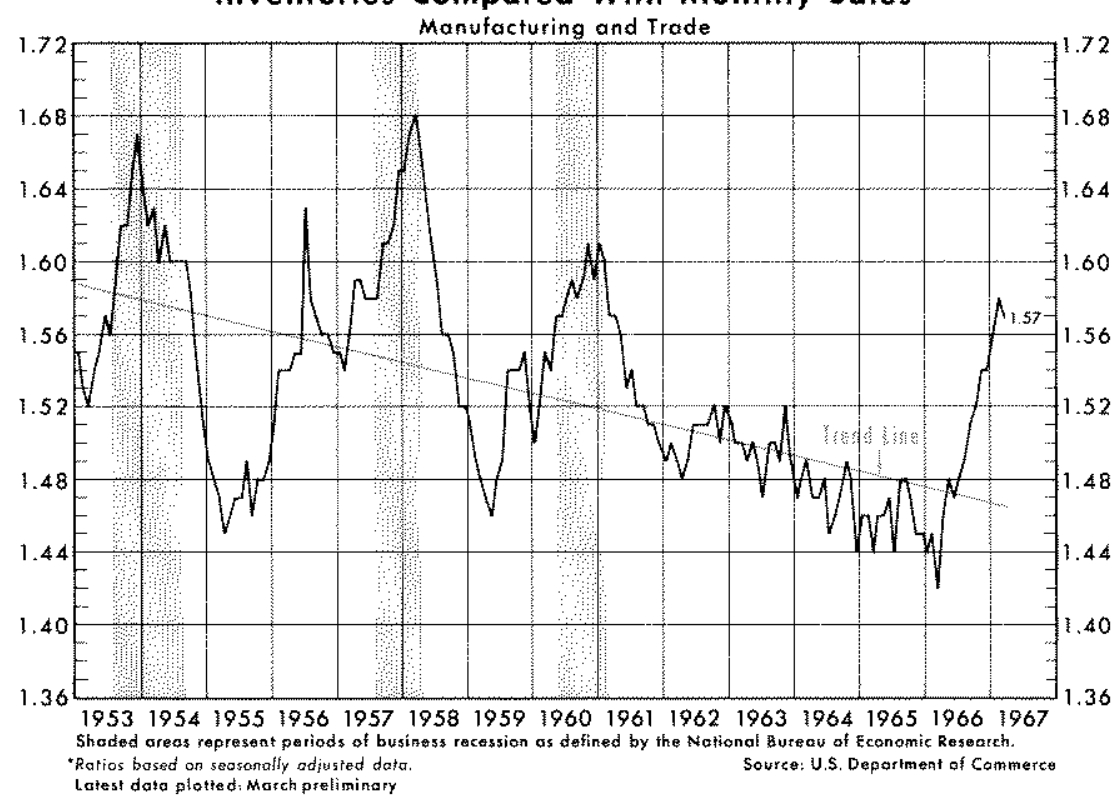

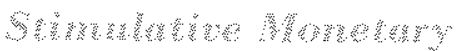

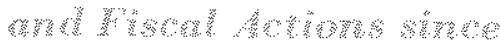

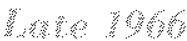

Government stabilization actions since late last year have been of a character generally regarded as stimulative. Monetary expansion has been rapid, and the Federal budget has become even more stimulative than in late 1966.

Monetary developments, which had been restrictive from last spring to late 1966, have since become quite expansionary. From October to April Federal Reserve open market operations added $\$ 3$ billion to reserves of member banks, a 14 per cent annual rate of increase. March reductions in legal reserve requirements on certain time deposits of member banks

the sharpest drop, declining about 22 per cent. Hog prices have fallen 31 per cent. Eggs and wool have recorded large price declines, dropping 24 and 22 per cent respectively. Although prices of farm products have declined sharply since their peaks of last August, they remain somewhat above the average for most recent years.

Much of the change in farm commodity prices can be traced to the current phase of the livestock production cycle. Production has been in a rising phase since late 1965, tending to depress prices. Livestock marketing may now have already reached a peak and may be expected to slow in the coming months. As a consequence farm prices will probably become firmer and perhaps start rising by the fall of the year.

Private demands for credit declined relative to supply in late 1966 as total spending grew more slowly. Consequently some interest rates (the price of loan funds) also declined. The rate on short-term commercial paper declined from 6 per cent in October 1966 to $5^{3 /}$ per cent in February and to $4 \frac{3}{4}$ per cent in early May. Yields on highest-grade long-term corporate bonds receded from the 5.5 per cent peak reached early last fall to 5 per cent in February. The average yield in early May was 5.15 per cent, up 15 basis points from the February low.

The excessive total demand and price inflation, which were of much concern during most of last year, have moderated. Whether this moderation is temporary or of a longer-run nature depends in considerable measure upon recent and forthcoming monetary and fiscal actions. had an effect similar to increasing reserves an additional $\$ 850$ million. As a result of these actions, a measure of Federal Reserve credit which includes member bank borrowing from Federal Reserve Banks and which is adjusted for changes in reserve requirements increased $\$ 3.2$ billion or at a 15 per cent annual rate from October to April. The interest rate at which Federal Reserve Banks lend to member banks was reduced from $4 \% 2$ to 4 per cent in early April. This move was generally considered a further sign of easier monetary policy.

Total bank reserves, reflecting the growth of Federal Reserve credit, increased $\$ 1.1$ billion or at a 10 per cent annual rate from October to April. These reserves had declined at a 2.3 per cent rate during the previous six months. A major share of these additional reserves was used as reserves required for time deposits. These deposits rose rapidly when interest rates paid on time deposits became attractive relative to other market rates.

In addition to reserves supplied for time deposit expansion, reserves available for private demand deposits increased at a 2.7 per cent rate from October to April. By comparison these reserves decreased at a 3.9 per cent rate from April 1966 to last October. Demand deposits, which had declined at a 3 per cent rate from April to October 1966, subsequently have increased at a 2.1 per cent rate. Money stock (private demand deposits plus currency in the hands of the public) showed a similar pattern, decreasing at a 1.5 per cent rate from April 1966 to last October and then rising at 


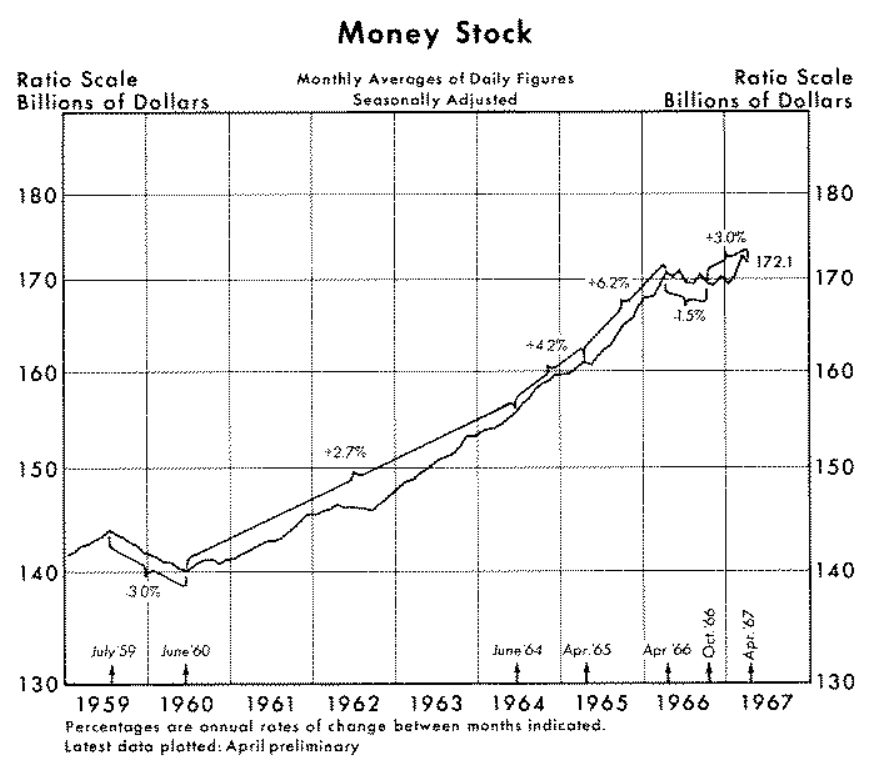

3 per cent rate. Since the first of the year this expansion has been at about a 5 per cent rate.

Fiscal developments have also been more expansionary in recent months. The Federal Government imparted an additional $\$ 4$ billion annual rate stimulus to the economy from the fourth quarter of last year to the first quarter, according to the high-employment budget. This was about $\$ 3$ billion more than was planned in the January budget, and reflected higherthan-expected Government expenditures. Defense spending, which has risen rapidly each quarter since mid-1965, continued its advance in the first quarter.

The deficit in the national income accounts budget is expected to exceed $\$ 9$ billion in the first quarter. This measure of budget developments reflects the slowdown in economic activity and its associated effect on tax receipts, as well as increased Government expenditures.

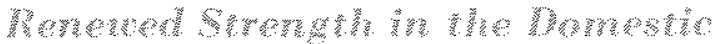

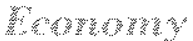

Some economic developments indicate that stimulative monetary and fiscal actions in the first few months of this year are now moving the economy upward from the plateau of late 1966 and early 1967. Such expansionary actions usually take some time to affect the economy. By now there is scattered evidence that some sectors of the economy are showing renewed strength. Retail sales in March increased sharply over February, and preliminary April figures indicate continuation of this strength. Construction outlays have risen since the first of the year. Capital market interest rates have firmed in recent months as new security offerings have been quite large.
A frequent topic of discussion among economic analysts at the present time is whether the upturn is now occurring or will be delayed to the third or fourth quarter. Some analysts have expressed concern that current Governmental actions, if continued much longer, may foster excessive demands and the renewal of inflation.

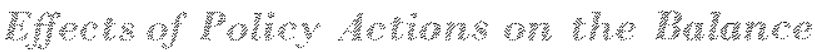

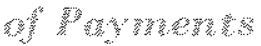

The recent expansionary monetary actions have stimulated an increase in the supply of credit. At the same time slower growth in total demand for goods and services contributed to a decline in the demand for credit. Both of these forces have contributed to lower interest rates. Some concern has been expressed that the decline in short-term interest rates will tend to aggravate the already serious U.S. balance-of-payments problem.

The rapid increase in interest rates in the summer of 1966 attracted a large amount of foreign funds into the United States and, to a lesser extent, encouraged some Americans to hold their dollar balances at home rather than depositing them abroad. ${ }^{1}$ It is feared by some that the current easing in financial markets and decline in interest rates in the United States will induce a sharp short-term capital outflow in 1967.

Preliminary evidence indicates that the balance-ofpayments deficit on the official settlements basis was at a faster rate in the first quarter of 1967 than in the last half of 1966 . This was due chiefly to the outflow of a significant portion of the short-term funds which came into the United States during the summer of 1966. Continued easing of domestic financial markets and U.S. interest rate declines could lead to a continued weakening balance of payments during the rest of 1967.

Comparison with 1960. Increased concern about the balance of payments in 1967 may be in part based on the 1960 experience. That was a year of softness in the United States domestic economy and of sharply declining interest rates. The decline in the demand for credit caused Treasury bill rates to decline from a peak of close to 5 per cent in early 1960 to 3 per cent in early 1961. At the same time rates were rising abroad, especially in the United Kingdom, Germany, and Canada. The resulting spread between U.S. and foreign interest rates lead to a sizable short-

\footnotetext{
1 Since American corporations have been cooperating in the President's voluntary program to strengthen the balance of payments, corporate short-term funds might not have been invested abroad even if U.S. short-term rates had not risen.
} 
term capital outflow from the United States. ${ }^{2}$

This outflow of funds, combined with the Presidential election uncertainties, led to foreign speculation about devaluation of the dollar. As a result there was a heavy run on the London gold market which pushed the free market price of gold from its normal range of around $\$ 35$ per ounce to close to $\$ 40$ per ounce. This speculative attack was subdued by the strong statement of President-elect Kennedy assuring maintenance of the international value of the dollar at $\$ 35$ per ounce of gold and by the development of institum tional arrangements among central banks to stabilize the London gold market.

Contrast with 1960. Although conditions in the United States in 1967 with respect to the decline in short-term interest rates are similar to those in 1960 , conditions abroad are not the same. The United Kingdom, Germany, and Canada, instead of having booming domestic economies and high interest rates, have recently been experiencing some economic weakness

2A large share of the recorded short-term outflow in 1960 was in the form of bank loans to Japan. This not only was due to high rates in Japan but also to a change in Japanese government policy in July 1960 , which made it much easier for Japanese banks to borrow short-term funds abroad.

\section{Yields on Euro-Dollar Deposits and Certificates of Deposit}

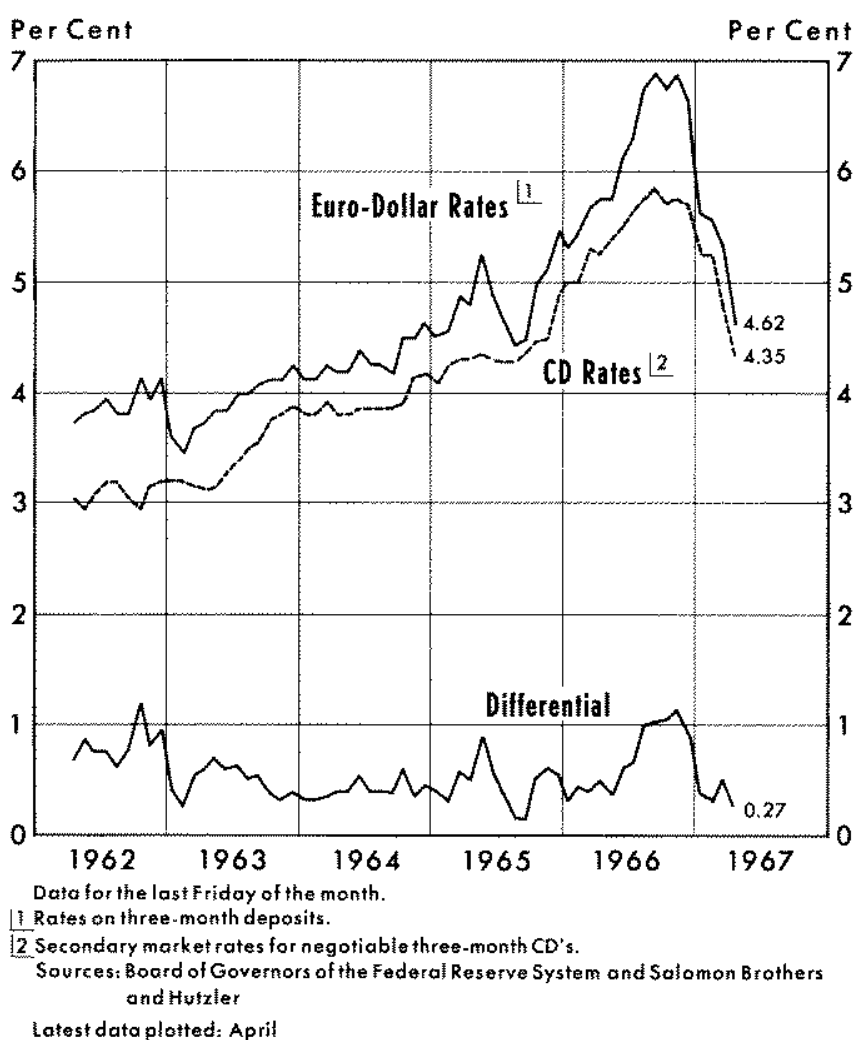

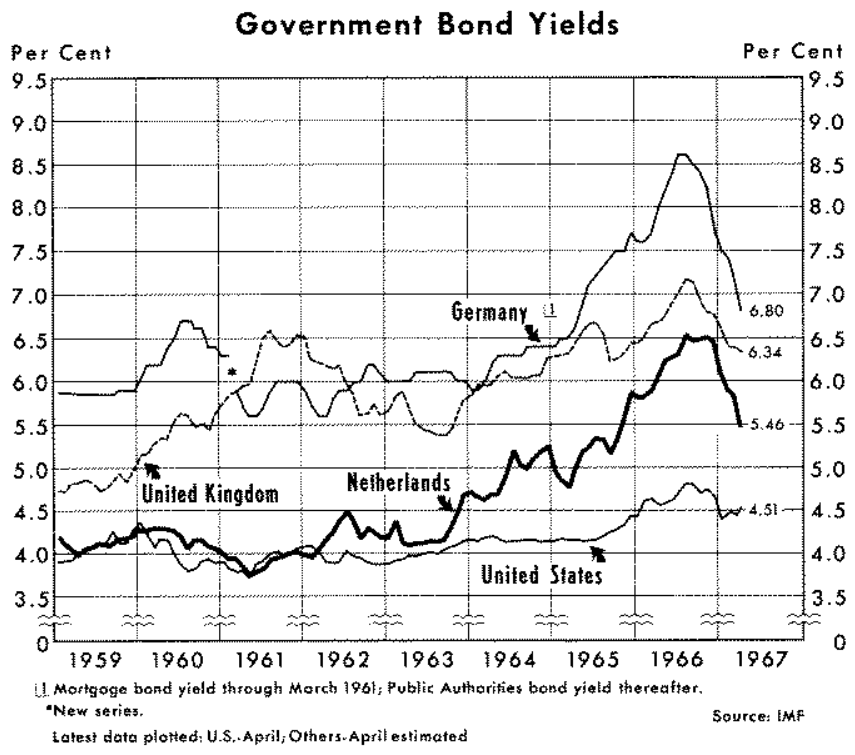

and softening in their interest rates. This is also true of the Netherlands, Belgium, Switzerland, and Sweden. Thus the incentive for moving short-term funds from the United States to these financial markets is not so strong this year as in 1960 .

Financial markets in France, Italy, and Japan also do not now provide attractive interest rate incentives for moving funds from the United States. Although the economies of these countries are relatively buoyant and their interest rates are rising, the absolute level of their rates is still not unusually favorable relative to rates in the United States.

Other important differences between the current situation and 1960 are the President's voluntary program initiated in February 1965 to support the balance of payments and the interest equalization tax (IET) initiated in July 1963. The voluntary program is designed to discourage banks from making loans and investments in developed countries and to encourage corporations to finance their foreign investments with funds obtained abroad. The IET on foreign securities is designed to discourage portfolio managers from investing abroad.

The different conditions existing in 1967 compared with 1960 are illustrated by developments in the Eurodollar market in the two periods. Since this market is sensitive to changes in international financial conditions, it tends to reflect net demand and supply conditions of many countries. In 1960 U.S. short-term rates declined as they are doing now, but the Eurodollar rates did not decline. Therefore, an unfavorable interest rate differential against the United States was created, and short-term funds flowed from the 
United States to Europe. By comparison, Euro-dollar rates have fallen even more rapidly in recent months than U.S. short-term rates on instruments of comparable liquidity, ${ }^{3}$ The reduced spread between these rates has thus provided less incentive for U.S. funds to move abroad.

${ }^{3}$ The Euro-dollar market is much larger now than in 1960 , and U.S. banks are participating more actively in it. The United States probably plays an important part in determining the Euro-dollat rate. Heavy bidding by U.S. banks in the summer of 1966 probably helped push this rate up, and the runoff of a large share of these funds since January has helped push this rate down.

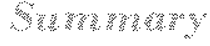

Stimulative monetary and fiscal actions since late 1966 are probably contributing to improvement in economic activity. Acceleration of total demand may be expected to develop as the full effect of these actions takes hold. The general decline in interest rates in late 1966 and early 1967 in most leading countries may enable the United States to continue to pursue a monetary policy directed at domestic considerations without seriously aggravating the balanceof-payments problem.

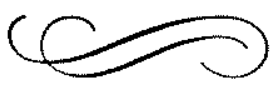

